\title{
The Relationship between Types of Hair Coloring with Hair Damages and Scalp Problems in Medical Students of University Sumatera Utara, Indonesia
}

\section{Abstract}

Introduction: Hair coloring is used to enhance beauty. It consist of two types, non permanent and permanent. Hair coloring could cause hair damages and scalp problems. The aim of our study is to study the relationship between type of hair coloring and hair damages and/ or scalp problems.

Method: It was an analytic study with cross-sectional method. This study was done in Faculty of Medicine in University Sumatera Utara (USU), Indonesia using total sampling technique.

Results: Of 300 students from batch 2011-2013 who performed hair coloring, 231 students (77,0\%) experienced hair damages. The type of hair damages mostly found were the combination of split ends and hair loss in 96 students (41.5\%). 193 students (64,3\%) experienced scalp problems, the commonest being scaly scalp in 87 students (45.1\%). Relationship between type of hair coloring with hair damages and scalp problems both were statistically significant $(p=0,0001)$.

Conclusion: It was concluded there is a significant relationship between hair coloring with hair damages and scalp problems.

\section{Introduction}

In society today, especially in teenagers, hair coloring is one of the important aspect of beauty enhancement other than straightening (rebonding), curling and others. [1] One of the essential ingredients in hair coloring is hydrogen peroxide $\left(\mathrm{H}_{2} \mathrm{O}_{2}\right)$, which gives color to the hair. The composition is different between the types of hair coloring. The content of hydrogen peroxide in the hair coloring can cause damage to the hair. [2]
Nelva Karmila Jusuf1, Yujinee Devi A/P

Subramaniam ${ }^{2}$

1 Dermatology Department, Faculty of Medicine in University Sumatera Utara, Indonesia.

2 Medicine student in University Sumatera Utara, Indonesia Batch 2011.

Contact information:

Nelva Karmila Jusuf, Yujinee Devi A/P Subramaniam.

झ nelva_jusuf@yahoo.com

$\risingdotseq$ yujineedevisubramaniam@yahoo.com

Keywords

Hair Coloring; Hair Damages; Scalp Problems. 
There are two types of hair coloring, non permanent and permanent. Non permanent hair coloring lasts for less than 6 weeks. An example is temporary hair coloring (temporary) and semi-permanent hair coloring. Non-permanent hair coloring is often used for special occasions, events, parties and Halloween. [3] Permanent hair coloring lasts for more than 6 weeks. Permanent hair coloring contains a developer, or oxidizing agent, and the alkaline ammonia agent. When a color that contain alkaline materials is combined with the developer (usually hydrogen peroxide). [4] Peroxide becomes alkaline and diffuses through the hair fiber, enters the cortex, where the melanin is located. Coloring occurs when the peroxide breaks down the melanin and replace it with a new color. Ammonia opens the hair cuticle so that the color pigment can penetrate deep into the hair shaft. Permanent hair color cannot be washed away, but it may fade. [5]

In the study conducted by Al-Ghamdi in Saudi Arabia (2011) [6], the type of hair coloring commonly used was permanent hair coloring; without performing an allergy test before coloring. Hair coloring can cause side effects due to changes in the structure of the hair; causing it to be dull, dry, brittle, suffer split ends, and eventually hair loss. Similarly, on the scalp, hair coloring can cause damage resulting in scaly scalp, dry, itchy, and so on. [7]

\section{Method}

This was an analytical study with cross-sectional sample of 300 female students at the Faculty of Medicine in USU, Indonesia who performed hair coloring. This study was conducted using total sampling. Respondents qualified the criteria of inclusions such as performance of hair coloring less than 6 months and acceptance of informed consent and criteria of exclusions such as who did straightening and or curling within 6 months, who suffered from high fever in 6 months, and who suffering from chronic diseases such as cancer, diabetes and systemic lupus erythematosus. Each respondent filled out a questionnaire containing 16 questions relating to the type of hair coloring, hair damages and scalp problems due to hair coloring. Analysis of the research employed the chi-square test. [8] Statistical significance was set of a prior at $p<0.05$.

\section{Results}

Table 1 shows about the relationship between types of hair coloring with hair damages. Table 2 shows about the relationship between types of hair coloring with scalp problems. Statistical analysis shows a significant relationship between type of hair coloring with hair damages $(p=0.0001)$ and scalp problems $(p=0.0001)$. Table 3 shows about the types of hair damages among students who perform hair coloring with majority of split ends and hair loss (41.5\%). Table 4 shows about the types of scalp problems with majority of scaly scalp (45.1\%) among the students.

Table 1. Relationship between Type of Hair Coloring with Hair damages.

\begin{tabular}{|c|c|c|c|c|c|c|}
\hline \multirow{3}{*}{$\begin{array}{c}\text { Type of } \\
\text { Hair Coloring }\end{array}$} & \multicolumn{4}{|c|}{ Hair damages } & \multirow{2}{*}{\multicolumn{2}{|c|}{ Total }} \\
\hline & \multicolumn{2}{|c|}{ Negative } & \multicolumn{2}{|c|}{ Positive } & & \\
\hline & $n$ & $\%$ & $\mathrm{~N}$ & $\%$ & $\mathrm{n}$ & $\%$ \\
\hline Non permanent & 55 & 18.3 & 100 & 33.3 & 155 & 51.7 \\
\hline Permanent & 14 & 4.7 & 131 & 43.7 & 145 & 48.3 \\
\hline Total & 69 & 23.0 & 231 & 77.0 & 300 & 100.0 \\
\hline
\end{tabular}

Table 2. Relationship between Type of Hair Coloring with Scalp problems.

\begin{tabular}{|l|c|c|c|c|c|c|}
\hline \multirow{2}{*}{\begin{tabular}{l}
\multirow{2}{*}{$\begin{array}{c}\text { Type of } \\
\text { Hair Coloring }\end{array}$} \\
\cline { 2 - 8 }
\end{tabular}} & \multicolumn{4}{|c|}{ Scalp problems } & \multicolumn{2}{c}{ Total } \\
\cline { 2 - 7 } & $\mathrm{n}$ & $\%$ & $\mathrm{~N}$ & $\%$ & $\mathrm{n}$ & $\%$ \\
\hline Non permanent & 83 & 27.7 & 72 & 24.0 & 155 & 51.7 \\
\hline Permanent & 24 & 8.0 & 121 & 40.3 & 145 & 48.3 \\
\hline Total & 107 & 35.7 & 193 & 64.3 & 300 & 100.0 \\
\hline
\end{tabular}


Table 3. Type of Hair damages.

\begin{tabular}{|c|l|c|c|}
\hline No & \multicolumn{1}{|c|}{ Type of Hair damages } & Total & $\begin{array}{c}\text { Percentage } \\
(\%)\end{array}$ \\
\hline 1 & Dull hair & 2 & 0.9 \\
\hline 2 & Dull hair and dry hair & 6 & 2.6 \\
\hline 3 & Dull hair and split ends & 16 & 6.9 \\
\hline 4 & Dry hair and split ends & 44 & 19.0 \\
\hline 5 & Brittle hair & 2 & 0.9 \\
\hline 6 & Brittle hair and split ends & 36 & 15.6 \\
\hline 7 & Split ends & 8 & 3.5 \\
\hline 8 & Split ends and hair loss & 96 & 41.5 \\
\hline 9 & Hair loss & 21 & 9.1 \\
\hline & Total & 231 & 100.0 \\
\hline
\end{tabular}

Table 4. Type of Scalp problems.

\begin{tabular}{|c|c|c|c|}
\hline No & Type of Scalp problems & Total & $\begin{array}{c}\text { Percentage } \\
(\%)\end{array}$ \\
\hline 1 & Itchiness & 10 & 5.2 \\
\hline 2 & $\begin{array}{l}\text { Itching and burning and scaly } \\
\text { scalp }\end{array}$ & 17 & 8.8 \\
\hline 3 & Itching and scaly scalp & 50 & 25.9 \\
\hline 4 & $\begin{array}{l}\text { Itching and scaly scalp and } \\
\text { reddish }\end{array}$ & 10 & 5.2 \\
\hline 5 & $\begin{array}{l}\text { Itching and scaly scalp and } \\
\text { swelling }\end{array}$ & 2 & 1.0 \\
\hline 6 & $\begin{array}{l}\text { Itching and scaly scalp and } \\
\text { injuries }\end{array}$ & 1 & 0.5 \\
\hline 7 & Scaly scalp & 87 & 45.1 \\
\hline 8 & Scaly scalp and reddish & 11 & 5.7 \\
\hline 9 & $\begin{array}{l}\text { Scaly scalp and redness and } \\
\text { swelling }\end{array}$ & 3 & 1.6 \\
\hline \multirow[t]{2}{*}{10} & Scaly scalp and injuries & 2 & 1.0 \\
\hline & Total & 193 & 100.0 \\
\hline
\end{tabular}

\section{Discussion}

This study conducted at the Faculty of Medicine in USU, Indonesia which found 300 respondents had performed hair coloring from batch 2011 to 2013. Hair plays an important role in human life as the crown of pride of women and men. [9] Other than hair coloring, hair styling such as hair straightening, curling and so on also have been performed by youngsters to modify their appearance. [10] In the previous study conducted by Aainaa \& Jusuf (2013), there was a significant relationship between hair straightening and curling with hair damage. [11]

In this study, total of 155 respondents (51.7\%) did non permanent hair coloring and 145 respondents (48.3\%) did permanent hair coloring. The permanent hair coloring composed in alkaline solutions in order to facilitate the penetration of chemicals pass through the cuticle. [12]

Table 1 shows that 100 respondents who did non permanent hair coloring and 131 respondents who did permanent hair coloring had experienced hair damages. From the results of statistical analysis with chi-square test, the $p=0.0001$ showed there is a significant relationship ( $p<0.05$ ) between the type of hair coloring with hair damages. It shows the type of hair coloring can cause side effects, because the substance used in hair coloring damages the cuticle layer that protects the hair. [13]

In table 2, we found 72 respondents who did non permanent hair coloring and 121 respondents who did permanent hair coloring experienced scalp problems. From the results of statistical analysis with chi-square test, the $p=0.0001$ showed there is a significant relationship ( $p<0.05$ ) between the type of hair coloring with scalp problems. It shows the type of hair coloring can cause side effects, because the substance used in hair coloring can cause problems such as allergic reactions and irritations on the scalp. [14]

In table 3, 231 respondents (77.0\%) experienced hair damages. In this study, types of hair damages mostly suffered by the respondents are the combinations of split ends and hair loss in 96 respondents (41.5\%). Chemicals such as ammonia, hydrogen peroxide, aniline contained in the hair coloring process can cause damage to the hair as the hair dull, dry hair, hair loss, split ends and brittle hair. [15]

In table 4, we found 193 respondents (64.3\%) experienced scalp problems from 300 respondents. In 
this study, types of scalp problems mostly suffered by respondents are scaly scalp in 87 respondents (45.1\%). Some cosmetics contain mild irritants that caused the reaction occurs after repeated use or long-term. [16]

\section{Conclusions and Suggestions}

The number of students who performed hair coloring and experienced hair damages were $77.0 \%$ and scalp problems were $64.3 \%$. Types of hair damages due to hair coloring were the combinations of split ends and hair loss in $41.5 \%$. Types of scalp problems due to hair coloring were scaly scalp in $45.1 \%$. There is a significant relationship between hair coloring with hair damages and scalp problems. However, further research needs to be done regarding to the relationship. The health worker should explained about the side effects due to hair coloring such as hair damages and scalp problems in order to further increase the insight and knowledge of the community. They also must consult with a dermatologist before perform hair coloring. Manufacturers of hairstyling products should provide warning signs to customers about the side effects that might result from the activity of hair coloring on the product package.

\section{Disclosure}

In this study, there is no conflict of interest.
6. AlGhamdi KM, Moussa NA, 2011. Knowledge and practices of, and attitudes towards, the use of hair dyes among females visiting a teaching hospital in Riyadh, Saudi Arabia. Available from: http://www.ncbi.nlm.nih.gov/pmc/articles/PMC3221134/ [Accesed from November-December 2011].

7. Iqbal M, 2012. Hubungan Pelurusan Rambut (Rebonding) dengan Kejadian Rambut Rontok. Available from: http://repository.usu.ac.id/handle/123456789/31211. [Accesed on 7 December 2012].

8. Wahyuni AS, 2008. Statistika Kedokteran. Bamboedoea Communication, Jakarta. 91.

9. Wolff K, Goldsmith LA, Katz SI, Gilchrest BA, Paller AS, Leffell DJ, 2012. Disorders Presenting in Skin and Mucous Membranes. In: Fitzpatrick's Wolff, K., Goldsmith, L.A., Katz, S.I., Gilchrest, B.A, Paller, A.S, Leffell, D.J., ed. Dermatology In General Medicine, Volume two $8^{\text {th }}$ Edition, McGraw-Hill, New York, 182-6.

10. Jusuf NK, 2014. Pengikalan dan Pelurusan Rambut In: Everything About Hair. Badan Penerbit Fakultas Kedokteran Universitas Indonesia, 161-70.

11. Aainaa N,Jusuf NK, 2013. Hubungan Pelurusan Rambut atau Pengeritingan Rambut dengan Kerusakan Rambut pada Mahasiswi Fakultas Kedokteran Universitas Sumatera Utara Angkatan 2009-2011. Karya Tulis IImiah Fakultas Kedokteran Universitas Sumatera Utara, Medan Indonesia.

12. Rahmadewi, 2014. Kosmetik yang Menginduksi Kerusakan Rambut In: Everything About Hair. Badan Penerbit Fakultas Kedokteran Universitas Indonesia, 171-9.

13. Harrison S, Sinclair R, 2003. Hair coloring, permanent styling and hair structure. Available from: http://www.ncbi.nlm.nih. gov/pubmed/17163926 [Accesed on 2 July 2003].

14. Krismi A, Sudibyo ES, Indrastuti N, 2008. Dermatitis Kontak Alergi Cat Rambut. Bagian/SMF IImu Kesehatan Kulit dan Kelamin, FK Universitas Gadjah Mada/ RS dr. Sardjito Yogyakarta. 124-8.

15. Jaffer S, Qureshi A, 2004. Dermatology Quick Glance. Mc Graw-Hill, United States, 150.

16. Tantari SHW, 2014. Efek Samping Kosmetik Rambut In: Everything About Hair. Badan Penerbit Fakultas Kedokteran Universitas Indonesia, 188-95.

\section{References}

1. Bolduc C, Shapiro J, 2001. Hair Care Products: Waving, Straightening, Conditioning, and Coloring. Clinic in Dermatology, Elsevier Science Inc. 431-6.

2. Kusumadewi, dkk., 2001. Pengetahuan dan Seni Tata Rambut Moderen. Jakarta: Meutia Cipta Sarana \& DPP. Tiara Kusuma, 19-36

3. Bariqina E, Ideawati Z, 2001. Perawatan \& Penataan Rambut. Percetakan Mitra Gama Widya.83-94.

4. Carbett JF, 1988. Hair coloring. Clinis in Dermatology, Department of Research and Development, Clairol, Inc., Stamford, Connecticut. 93-101.

5. Brown RG, Burns T, 2005. Dermatology Eighth Edition. Jakarta: Erlangga, 133-41.

Publish in International Archives of Medicine

International Archives of Medicine is an open access journal publishing articles encompassing all aspects of medical science and clinical practice. IAM is considered a megajournal with independent sections on all areas of medicine. IAM is a really international journal with authors and board members from all around the world. The journal is widely indexed and classified Q1 in category Medicine. 